\section{The two sides of mineralogy}

\section{R.A. Howie}

Mineralogy: Concepts, Descriptions,

Determinations, 2nd Edn.

By L.G. Berry, Brian Mason and

R.V. Dietrich

W.H. Freeman: 1983. Pp.561.

$\$ 35.95, £ 30.95$.

THE first edition of Mineralogy appeared in 1959, so the book has long been due for an overhaul. This new edition has undergone extensive revision, and is intended not only as a textbook for a first course in mineralogy but also as a reference work for geologists, pedologists, solid-state physicists and others who use crystallography or mineralogy in their work.

Additions include brief accounts of the phase rule, phase equilibrium diagrams, Pauling's rules, optical mineralogy techniques, and applications of the electron microprobe; sections dealing with the gnomonic projection and blowpipe analysis have been discarded. Specific locality and production data, previously included in the mineral descriptions, are also omitted.

The text falls into two main parts, the first dealing with crystallography, crystal chemistry, physical and optical properties and determinative techniques, while the second provides descriptions of some 200 minerals. The latter section includes fairly extensive coverage of sulphides and sulphosalts, nitrates, borates, chromates, molybdates, arsenates, vanadates and so on, in addition to the rock-forming minerals of the oxide, sulphate, carbonate and silicate groups. The book may thus be compared with the second edition of M.H. Battey's Mineralogy for Students (Longman, 1981; for review see Nature 295,$464 ; 1982$ ) and will be of particular relevance to students of mining and economic geology.

Fairly minor criticisms are that the notes on the optical indicatrix and the determination of optic sign are surely so brief as to provide little help to the student seeking to reproduce some of the optical data in the determinative tables (which form Part III of the book). The concept of extinction angle is mentioned in Part I but no extinction angles are listed in the descriptive sections, though cell parameters and space groups are given for each species.

My overall impression of this second edition is that it has been considerably improved (the diagrams and line drawings are particularly clear) but that it is trying to cover too much. In view of the reluctance of some students to buy more than one book for each course it is no doubt sensible and certainly convenient to include techniques and properties together in one volume, but it leads to a rather superficial coverage of many topics.

R.A. Howie is Professor of Mineralogy at King's College, University of London.

in which case each is treated separately, before Maynard leads on to discussion of mineralogy then geochemistry. Calculated equilibrium phase diagrams are used extensively - some familiarity with these is assumed - and there is also frequent reference to stable isotope geochemistry. Each section closes with descriptions of specific orebodies and an account of how they might have formed.

Brief descriptions of numerous orebodies from around the world are included in the book and given a separate index separate that is from author and subject indexes. The bibliography is extensive and up to date. I found these features very useful. My initial overall impression was that too much reliance had been placed on equilibrium relationships amongst minerals, but this, perhaps, was unfair since Maynard gives an explicit appraisal of his approach and its limitations in the introductory chapter.

I liked this book: it brings together traditional economic geology and modern geochemistry in a constructive way. I'm sure it will make a good textbook for a graduate course, which indeed is how it originated.

Charles Curtis is Professor of Geochemistry at the University of Sheffield.

\section{Sediments, processes and time}

\author{
J.R.L. Allen
}

Practical Sedimentology.

By D.W. Lewis.

Hutchinson Ross: 1984. Pp.229.

Pbk \$22.95, f22.25.

Depositional Systems: A Genetic

Approach to Sedimentary Geology.

By Richard A. Davis, Jr.

Prentice-Hall: 1983. Pp.669.

$\$ 48.55$, £34.15.

Dynamic Stratigraphy: An Introduction to Sedimentation and Stratigraphy, and Edn.

By Robley K. Matthews.

Prentice-Hall: 1983. Pp.489.

$\$ 44.50, £ 31.30$.

THE extraordinary growth of interest in sedimentology over the past twenty years continues to provoke the frequent publication of new student texts. Their diversity of scope, aims and methods is a healthy sign in such a young subject, which has still to define its true identity and aims. Is sedimentology about the history of sedimentary deposits (the "stratigraphical" root of the subject), or is it largely concerned with the mechanisms and processes which at every level shape such deposits (the "geophysical-geochemical-geobiological" root)? The three books reviewed here draw strength in very different degrees from these two sources.

In Practical Sedimentology we learn that the role of the sedimentologist is "to interpret the history of sedimentary deposits". Dr Lewis's book exemplifying this theme is in twelve chapters, covering environments and processes of sedimentation, textures and composition of detrital sediments, sedimentary carbonates, evaporite deposits, iron in sedimentation, introduction to well-logging, map varieties and suggestions for fieldwork.

It is good to see attention given in a student text to down-hole methods, but my unease about this book stems from its unimaginativeness and narrowness of outlook, and a feeling that the author had not decided whether he was writing a practical manual or a text to cover principles. The range of practical techniques described is limited and their treatment commonly superficial and lacking in illustrations. The lay-out adopted by the publishers is thoroughly confusing. There is no hint that, using simple equipment and readily available materials, the student can explore experimentally many important sedimentary phenomena, and thereby strengthen insight into what is essentially dynamic. Practical Sedimentology cannot be said to fit the bill for a modern and all-round manual of do-it-yourself laboratory and field sedimentology. 